\title{
The Angiotensin AT2-Receptor Mediates Inhibition of Cell Proliferation in Coronary Endothelial Cells
}

\author{
Monika Stoll, U. Muscha Steckelings, Martin Paul, ${ }^{\star}$ Serge P. Bottari, ${ }^{*}$ Rainer Metzger, and Thomas Unger \\ Department of Pharmacology, University of Kiel, 24105 Kiel, Germany; *Max-Delbrück Center for Molecular Medicine, Berlin, \\ Germany; and ${ }^{\ddagger}$ Centre d’ Etudes Nucleaires de Grenoble, Inserm U.244, Grenoble Cedex, France
}

\begin{abstract}
Angiotensin II (ANG II) is known to be a potent growth promoting factor for vascular smooth muscle cells and fibroblasts but little is known about its influence on growth in endothelial cells. We studied the effects of ANG II on endothelial growth and the role of the angiotensin receptor subtypes involved. Proliferation of rat coronary endothelial cells (CEC) and rat vascular smooth muscle cells (VSMC) was determined by $\left[{ }^{3} \mathrm{H}\right]$ thymidine incorporation, the MTTtest and by directly counting cells in a coulter counter. Angiotensin AT1- and AT2-receptors were demonstrated by binding studies and by the presence of their respective mRNA through reverse transcription polymerase chain reaction (RT-PCR).

In contrast to VSMC, which in culture only express the AT1-receptor, CEC express both, AT1- and AT2-receptors simultaneously up to the third passage. Whereas ANG II stimulated growth of quiescent VSMC, an effect abolished by pretreatment with the AT1-receptor antagonist, losartan, ANG II did not induce proliferation in quiescent CEC. However, after pretreatment of quiescent endothelial cells ( < passage 4) with the AT2-receptor antagonist, PD 123177, ANG II induced proliferation. This effect was reversed by additional pretreatment with losartan. ANG II significantly inhibited the proliferation of bFGF-stimulated CEC in a dose-dependent manner by maximally $50 \%$. This effect was prevented by PD 123177 while losartan was ineffective. The AT2-receptor agonist, CGP 42112, mimicked the antiproliferative actions of ANG II, confirming the specificity of the effect.

Our results show that the growth modulating actions of ANG II depend on the type of angiotensin receptor present on a given cell. In coronary endothelial cells, the antiproliferative actions of the AT2-receptor offset the growth promoting effects mediated by the AT1-receptor. (J. Clin. Invest. 1995. 95:651-657.) Key words: angiotensin receptors - bFGF • endothelial cells • PD 123177 • CGP 42112 • Losar$\tan \cdot \mathbf{R T}-\mathbf{P C R}$
\end{abstract}

Address correspondence to Monika Stoll, Ph.D., Department of Pharmacology, Christian-Albrechts-Universität zu Kiel, Hospitalstr. 4, 24105 Kiel, Germany. Phone: 431-5973501; FAX: 431-5973522.

Received for publication 25 January 1994 and in revised form 13 October 1994.

J. Clin. Invest.

(C) The American Society for Clinical Investigation, Inc.

0021-9738/95/02/0651/07 \$2.00

Volume 95, February 1995, 651-657

\section{Introduction}

Angiotensin II (ANG II), ${ }^{1}$ the main effector peptide of the renin-angiotensin system, has long been known to play an important role in the regulation of blood pressure and body fluid homeostasis. More recently, ANG II has been reported to induce hyperplasia or hypertrophy in cultured vascular smooth muscle cells derived from the aorta (1-4), in small resistance arteries (5) and in cardiomyocytes (6).

We have previously observed that chronic oral treatment of spontaneously hypertensive rats (SHR) with an angiotensin converting enzyme inhibitor induced myocardial capillary growth independently of the antihypertensive and antihypertrophic actions of the drug (7). Theoretically, this effect could be due to a potentiation of endogenous kinins or to a reduced generation of ANG II. In the latter case, one would have to expect an antiproliferative effect of ANG II on myocardial endothelial cells which gives rise to cardiac capillaries. This hypothesis is at variance with the widely accepted idea of ANG II being a growth promoting factor in cardiovascular tissues. However, using coronary endothelial cells (CEC) from SHR and normotensive Wistar Kyoto rats in primary culture, we recently found that ANG II significantly attenuated proliferation when growth was stimulated by fetal calf serum $(8,9)$. Thus, in contrast to its proliferating effects on vascular smooth muscle cells (VSMC), ANG II may indeed exert antiproliferative actions on vascular endothelial cells.

VSMC in culture, a common cell line to study the trophic effects of ANG II, exclusively express AT1- and no AT2-receptors (10). Therefore, ANG II-induced growth shown in VSMC in vitro has been attributed to the AT1-receptor. The obvious discrepancy between the effects of ANG II on VSMC and on microvascular endothelial cells could be explained twofold. First, angiotensin receptors on endothelial cells could be identical to those on VSMC (i.e., AT1) but coupled to intracellular pathways different from those present in VSMC. Second, the antiproliferative response to treatment with ANG II, as observed in endothelial cells, could be due to the stimulation of an angiotensin receptor subtype different from AT1, for instance the AT2-receptor. In addition, the antiproliferative effect of ANG II could be a phenomenon occurring in serum-stimulated rat cardiac microvascular endothelial cells but not a general feature of CEC under stimulation with defined growth factors.

In the present study we investigated, first, whether ANG II is antimitogenic for CEC stimulated to proliferate by the administration of a defined growth factor and second, by which angiotensin receptor subtype, AT1 or AT2, the antimitogenic

1. Abbreviations used in this paper: ANG II, angiotensin II; bFGF, basic FGF; CEC, coronary endothelial cells; SHR, spontaneously hypertensive rats; VSMC, vascular smooth muscle cells. 
effect of ANG II is mediated. Using different test systems, $\left[{ }^{3} \mathrm{H}\right]$ thymidine incorporation, the MTT proliferation assay and cell counts, we demonstrate that ANG II significantly inhibits growth in bFGF-stimulated coronary endothelial cells and that this effect is mediated by the AT2-receptor. Our results suggest that the presence of the respective angiotensin receptor subtypes, AT1 and AT2, on a given cell determines whether the peptide exerts proliferative or antiproliferative actions.

\section{Methods}

Cell culture. VSMC were isolated from rat aortae by enzymatic digestion as previously described (3). VSMC were cultured in medium containing a 1:1 formulation of DME and HAM's F12 medium, supplemented with $10 \%$ FCS, L-glutamine ( $1 \mathrm{mM})$, penicillin $(100 \mathrm{U} / \mathrm{ml})$ and streptomycin $(100 \mu \mathrm{g} / \mathrm{ml})$. Cells were harvested for passaging at subconfluence with a trypsin-EDTA ( $0.25 \%$ trypsin and $0.02 \%$ EDTA) solution. VSMC identity and the purity of cultures were verified by immunohistochemical analysis using a monoclonal antibody for smooth muscle $\alpha$-actin.

Rat CEC were isolated as described by Piper et al. (11). In brief, hearts from anesthetized and heparinized (intraperitoneal injection of $60 \mathrm{mg} / \mathrm{ml}$ per $\mathrm{kg}$ sodium pentobarbital and 5,000 I.U. sodium heparin) male SHR weighing 180-250 $\mathrm{g}$ were excised and mounted via the aorta to a Langendorff perfusion system. Nonrecirculating perfusion was started immediately at a flow rate of $10 \mathrm{ml} / \mathrm{min}$ with a modified Krebs-Henseleit solution containing $110 \mathrm{mM} \mathrm{NaCl}, 2.6 \mathrm{mM} \mathrm{KCl}, 1.2$ $\mathrm{mM} \mathrm{KH}_{2} \mathrm{PO}_{4}, 1.2 \mathrm{mM} \mathrm{NaHCO}_{3}, 11 \mathrm{mM}$ glucose and gassed with carbogen $\left(95 \% \mathrm{O}_{2}, 5 \% \mathrm{CO}_{2}\right)$. After $5 \mathrm{~min}$, perfusion was switched to recirculating mode with Krebs-Henseleit solution supplemented with $136 \mathrm{U} /$ $\mathrm{ml}$ Collagenase (Worthington CLS II), $25 \mathrm{U} / \mathrm{ml}$ Dispase (grade I) and $5 \mathrm{U} / \mathrm{ml}$ trypsin. After $30 \mathrm{~min}$ of perfusion, atria were discarded, the ventricles minced and again incubated in protease solution. The cell homogenate was filtered through a nylon mesh $(200 \mu \mathrm{m})$ and centrifuged at $25 \mathrm{~g}$ for $3 \mathrm{~min}$. The supernatant was further dissociated for $30 \mathrm{~min}$ with protease solution containing $4 \%$ bovine serum albumine (BSA) and trypsin $(5 \mathrm{U} / \mathrm{ml})$. Cells were seeded on collagen A (containing $\sim 975 \%$ collagen type I and 3\% type IV)-precoated dishes and cultured in DME supplemented with $20 \%$ FCS, $50 \mu \mathrm{g} / \mathrm{ml}$ endothelial cell growth supplement and $50 \mu \mathrm{g} / \mathrm{ml}$ heparin.

Cells were harvested for passaging at subconfluence with a trypsinEDTA (0.05\% trypsin and $0.02 \%$ EDTA) solution. Endothelial cells were characterized by their cobblestone morphology and the presence of the receptor for acetylated LDL (12). Purity of culture was verified by the lack of staining with a monoclonal antibody for smooth muscle $\alpha$-actin to exclude pericyte contamination.

Cell cultures were incubated at $37^{\circ} \mathrm{C}$ in a humified atmosphere of $5 \% \mathrm{CO}_{2}-95 \%$ air. VSMC were used from passages $10-28, \mathrm{CEC}$ were used exclusively up to the third passage.

$\left[{ }^{3} \mathrm{H}\right]$ Thymidine incorporation. Relative rates of DNA synthesis were determined by $\left[{ }^{3} \mathrm{H}\right]$ thymidine incorporation following the method of Glaser et al. (13) with slight modifications. Briefly, cells were incubated for $4 \mathrm{~h}$ with $1 \mu \mathrm{Ci} /$ well [ methyl, $1^{\prime}, 2^{\prime}-{ }^{3} \mathrm{H}$ ] thymidine in serum-free medium. Cells were rinsed twice with cold phosphate-buffered saline ( 124 $\mathrm{mM} \mathrm{Nacl}, 2.8 \mathrm{mM} \mathrm{KCl}, 8.1 \mathrm{mM} \mathrm{Na}_{2} \mathrm{HPO}_{4}, 1.5 \mathrm{mM} \mathrm{KH}_{2} \mathrm{PO}_{4}$, and 0.5 $\mathrm{mM} \mathrm{MgCl}_{2}$ ) and prefixed for $3 \mathrm{~min}$ with a formulation of 1:1 PBS/ fixative ( $70 \%$ ethanol $/ 30 \%$ acetic acid). Cells were then fixed in fixative for $20 \mathrm{~min}$ at $37^{\circ} \mathrm{C}$ and for $10 \mathrm{~min}$ with $0.3 \mathrm{M}$ perchloric acid, followed by a thorough rinse with distilled water. The fixed cells were incubated for $20 \mathrm{~min}$ in $100 \mu \mathrm{l}$ of a $0.25 \mathrm{M} \mathrm{NaOH}$ before an equal volume of distilled water was added. The hydrolysate was than transferred to scintillation vials with $3 \mathrm{ml}$ of scintillation fluid, and samples were counted for $5 \mathrm{~min}$ in a beta-counter.

Proliferation assay. Cell proliferation was measured using the CellTiter $96^{\mathrm{TM}}$ Cell Proliferation Assay (Promega, Merdeson, WI), which uses cellular conversion of a tetrazolium salt into a blue formazan product (MTT-test) (14). Absorbance was measured in an ELISA-reader at
570 and $620 \mathrm{~nm}$ (for reference) and was used as a parameter for cell number. Additionally, cell number was directly determined using a Coulter particle counter as described previously (15) with slight modifications.

Experimental protocol. For $\left[{ }^{3} \mathrm{H}\right]$ thymidine incorporation and MTTtest cells were seeded subconfluently on collagen A-precoated 96multiwell plates and for determination of cell number by cell count on 24-multiwell plates. Quiescence was achieved by serum deprivation in standard culture medium supplemented with $1 \%$ FCS for at least $48 \mathrm{~h}$. The following experiments were then performed. Treatment of quiescent cells with ANG II $\left(10^{-10}\right.$ to $\left.10^{-6} \mathrm{M}, n=10\right)$, with ANG II $\left(10^{-7} \mathrm{M}\right)$ after pretreatment with the respective AT1- and AT2-receptor antagonists, losartan and PD $123177\left(10^{-7}\right.$ to $\left.10^{-5} \mathrm{M}, n=8\right)$, and the AT2agonist, CGP $42112\left(10^{-8}\right.$ to $\left.10^{-6} \mathrm{M}\right)$, or with the angiotensin receptor ligands plus vehicle as controls $(n=8)$. $\left[{ }^{3} \mathrm{H}\right]$ Thymidine incorporation and proliferation, respectively, were measured 40 to $48 \mathrm{~h}$ later as described above. In a second set of experiments, proliferation of quiescent cells was induced by the addition of $25 \mathrm{ng} / \mathrm{ml}$ bFGF for $24 \mathrm{~h}$ followed by drug treatment of the cells as above. $\left[{ }^{3} \mathrm{H}\right]$ Thymidine incorporation and proliferation were determined $24 \mathrm{~h}$ later ( $n=10$ for each group).

Angiotensin receptor binding studies. Cells at their second passage were serum deprived for $48 \mathrm{~h}$, harvested with trypsin/EDTA and immediately washed three times with ice-cold PBS. Membrane particulate was prepared according to a previously described method (16). Briefly, harvested cells were homogenized in ice-cold buffer $(20 \mathrm{mM}$ Tris, $\mathrm{pH}$ 7.4, $1 \mathrm{mM}$ EDTA, $0.1 \%$ BSA, $2 \mathrm{mM}$ benzamidin and $0.01 \%$ bacitracin) with a Dounce homogenizer. Homogenates were centrifuged twice at $1,000 \mathrm{~g}$ for $10 \mathrm{~min}$ and the supernatants at $30,000 \mathrm{~g}$ for $45 \mathrm{~min}$. The resulting pellet was resuspended in $20 \mathrm{mM}$ Tris, pH 7.6, $1 \mathrm{mM}$ EDTA at a concentration of $2 \mathrm{mg} / \mathrm{ml}$ and snap-frozen in liquid nitrogen. Protein content was determined using the Coomassie Plus Protein Assay Reagent (Pierce, Rockford, IL) with bovine serum albumin (BSA) as standard.

For competition binding experiments, membrane particulate was incubated in $200 \mu$ l binding buffer ( $50 \mathrm{mM}$ Tris, pH 7.4, $125 \mathrm{mM} \mathrm{NaCl}$, $6.5 \mathrm{mM} \mathrm{MgCl}_{2}, 1 \mathrm{mM}$ EDTA, $0.2 \%$ BSA, $1 \mathrm{mM}$ benzamidin, $0.01 \%$ bacitracin and antipain, phosphoramidon, pepstatin $\mathrm{A}$, bestatin, leupeptin and amastatin (all at $1 \mu \mathrm{g} / \mathrm{ml}$ ) at a final concentration of $350 \mu \mathrm{g} /$ $\mathrm{ml}$ for $90 \mathrm{~min}$ at $25^{\circ} \mathrm{C}$ in the presence of $\left[{ }^{125} \mathrm{I}\right] \mathrm{Sar}^{1} \mathrm{Ile}^{8} \mathrm{ANG}$ II $(0.25$ $\mathrm{nM}$ ) as a tracer and of losartan or CGP 42112 as respectively selective AT1 and AT2 competitors. The reaction was stopped with $3 \mathrm{ml}$ of icecold PBS, and bound ligand was separated from free by filtration through glass-fiber filters (Whatman GF/F, Clifton, NJ) coated with $1 \%$ BSA. Nonspecific binding was determined in the presence of $1 \mu \mathrm{M}$ ANG II and was less than $10 \%$ of total binding. Specific binding was calculated by subtracting non-specific from total binding. Degradation of [ $\left.{ }^{125} \mathrm{I}\right] \mathrm{Sar}-$ ${ }^{1} \mathrm{Ile}^{8}$ ANG II as measured by thin-layer chromatography was $<5 \%$. Data are the mean of three experiments analyzed with the EBDA-LIGAND programme (17).

PCR analysis of AT1 and AT2 expression. The mRNA expression of the AT1 and AT2 sequences was measured using RT-PCR assays. The total RNA was extracted based on the protocol of Chirgwin et al. (18). After first-strand synthesis of RNA using random hexamers as described (19) cDNA was amplified using specific primers. For amplification of AT1, the antisense primer was GCCCTGTCCACAATATCTGC (extending from base 1108 through base 1127) and the sense primer TGTAAGATTGCTTCAGCCAGC (extending from base 581 through base 601) was used. For amplification of AT2, the antisense primer was ACCACTGAGCATATTTCTCGGG (base 682 through base 703) and the sense primer TGAGTCCGCATTTAACTGC (base 227 through base 245 ). The amplification protocol followed the procedure originally described by Paul et al. (19). After amplification, sequences were blotted onto nylon membranes hybridized to full length cDNA probes of AT1 and AT2, respectively, as described (19). The radioactive signals were then analyzed using a computer based imaging system (Fuji BAS 2000)

Reagents. DME, HAM's F12 medium, FCS, L-glutamine, sodium 
pyruvate, non-essential amino acids, antibiotics and murine leukemia virus reverse transcriptase (MULV-RT) were obtained from GIBCO BRL (Eggenstein, Germany). Trypsin, Dispase, dATP, dCTP, dTTP, dGTP, RNAsin, and random hexamers were purchased from Boehringer (Mannheim, Germany), and Taq Polymerase was from Perkin Elmer/ Cetus (Norwalk, CT). Collagenase and collagen A were supplied by Biochrom (Berlin, Germany), the CellTiter $96^{\mathrm{TM}}$ Proliferation Assay was from Promega. PD 123177 was obtained from Parke Davis Pharmaceutical Research (Ann Arbor, MI). Losartan was a gift from Dr. R. Smith, DuPont Merck Pharmaceutical Company (Wilmington, DE), and CGP 42112 was obtained from Ciba-Geigy Ltd. (Basel, Switzerland). ANG II was purchased from Bachem, Bubendorf, Switzerland. $\left[{ }^{125} \mathrm{I}\right] \mathrm{Sar}^{1} \mathrm{Ile}^{8}$ ANG II and [methyl-1 $\left.1^{\prime}-2^{\prime}-{ }^{3} \mathrm{H}\right]$ thymidine and $\left[{ }^{32} \mathrm{P}\right]$ dCTP were obtained from Amersham (Braunschweig, Germany). All other reagents used were of highest commercially available grade.

Statistics. Data are reported as means of at least six experiments (each in triplicate) \pm SEM. Statistical analysis on the raw data was performed by one-way analysis of variance (ANOVA) followed by appropriate post-hoc tests (Student's $t$ test, Bonferroni) for comparison between groups. A probability of $\mathbf{0 . 0 5}$ or less was considered significant. Details of the statistical comparisons are given in the legends to the figures.

\section{Results}

Effects of ANG II on $\left[{ }^{3} \mathrm{H}\right]$ thymidine uptake and proliferation. ANG II was tested for its ability to stimulate the proliferation of quiescent microvascular CEC and aortic VSMC or to influence the mitogenic activity of proliferating CEC after stimulation with $25 \mathrm{ng} / \mathrm{ml}$ bFGF.

Application of ANG II $\left(10^{-10}\right.$ to $\left.10^{-6} \mathrm{M}\right)$ to quiescent CEC did not exert any significant actions on $\left[{ }^{3} \mathrm{H}\right]$ thymidine uptake or cell number (MTT-test: extinction $0.113 \pm 0.022$ for vehicletreated CEC vs. $0.111 \pm 0.025$ for ANG II $\left(10^{-7} \mathrm{M}\right)$-treated CEC). Fig. $1 b$ shows the respective data for $\left[{ }^{3} \mathrm{H}\right]$ thymidine incorporation with an ANG II concentration of $10^{-7} \mathrm{M}$. In contrast, a significant increase in $\left[{ }^{3} \mathrm{H}\right]$ thymidine incorporation could be observed after treatment of quiescent VSMC with ANG II at higher concentrations $\left(10^{-7}\right.$ to $\left.10^{-6} \mathrm{M}\right)$ (Fig. $\left.1 a\right)$, while cell number was not influenced (MTT-test: extinction $0.211 \pm 0.010$ for vehicle-treated VSMC versus $0.200 \pm 0.003$ for ANG II-treated VSMC). The ANG II-induced increase in $\left[{ }^{3} \mathrm{H}\right]-$ thymidine uptake in VSMC was prevented by the specific AT1receptor antagonist, losartan, but was not influenced by the specific AT2-receptor antagonist, PD 123177 (Fig. 1 a). In quiescent CEC, losartan pretreatment slightly reduced $\left[{ }^{3} \mathrm{H}\right]-$ thymidine uptake after ANG II (Fig. $1 b$ ) while having no effect when given alone (data not shown). In contrast, when quiescent CEC were pretreated with PD $123177,\left[{ }^{3} \mathrm{H}\right]$ thymidine uptake was induced by ANG II (Fig. $1 b$ ). This effect was abolished when cells were pretreated with losartan in addition to PD 123177 (Fig. $1 b$ ). Comparable results were obtained when cell number was directly determined by a Coulter particle counter (Table I).

Treatment of CEC with ANG II $\left(10^{-9}\right.$ to $\left.10^{-6} \mathrm{M}\right) 24 \mathrm{~h}$ after stimulation with $25 \mathrm{ng} / \mathrm{ml}$ bFGF led to a dose-dependent decrease in $\left[{ }^{3} \mathrm{H}\right]$ thymidin uptake compared with vehicle-treated cells. This antimitogenic effect of ANG II was maximal at a concentration of $10^{-6} \mathrm{M}$, when proliferation of CEC was inhibited by more than $50 \%$ (Fig. 2, $a$ and $b$ ) compared with vehicletreated controls. The decrease in $\left[{ }^{3} \mathrm{H}\right]$ thymidine incorporation was accompanied by a similar decrease in conversion of MTT and cell number (Table I) compared with vehicle-treated prolif-

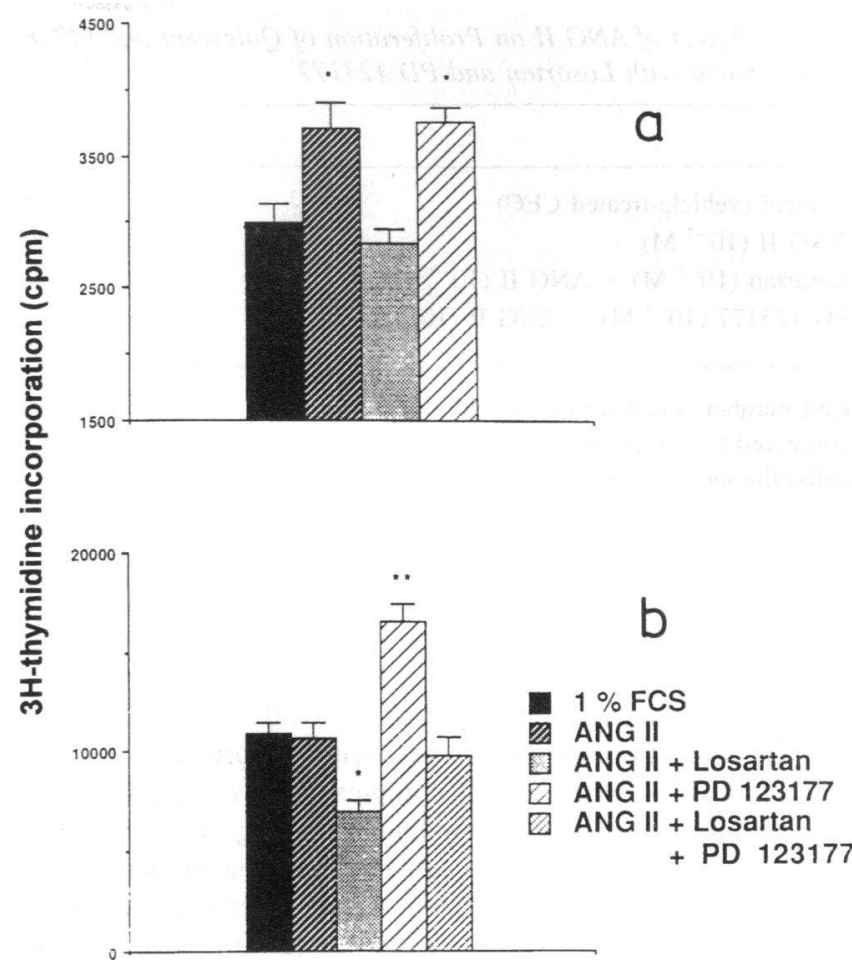

Figure 1. Effect of ANG II $\left(10^{-7} \mathrm{M}\right)$ on $\left[{ }^{3} \mathrm{H}\right]$ thymidine incorporation in quiescent cells with or without pretreatment with the specific ANG II receptor antagonists, losartan $\left(10^{-5} \mathrm{M}\right)$ and PD $123177\left(10^{-6} \mathrm{M}\right)$, in comparison to vehicle treated cells $(n=8)$. (a) ANG II stimulated the uptake of $\left[{ }^{3} \mathrm{H}\right]$ thymidine in VSMC. This effect was blocked by losartan but not by PD 123177. ${ }^{*} P<0.05, * * P<0.01$ in comparison to vehicle-treated cells. $(b)$ CEC derived from SHR: ANG II was mitogenic when the AT1-receptor was unmasked by blockade of the AT2receptor with PD 123177, while ANG II alone or after pretreatment with the AT1-receptor antagonist, losartan, was ineffective.

erating cells. (MTT-test: extinction $0.127 \pm 0.004$ for ANG II $\left(10^{-7} \mathrm{M}\right)$ vs. $0.152 \pm 0.005$ in controls; $\left.P<0.01\right)$.

To characterize the angiotensin receptor subtype involved in the antimitogenic action of ANG II, we examined the influence of ANG II $\left(10^{-7} \mathrm{M}\right)$ on endothelial cell $\left[{ }^{3} \mathrm{H}\right]$ thymidine incorporation in the presence of losartan and PD 123177 (both $10^{-7}$ to $\left.10^{-5} \mathrm{M}\right)$. Treatment of the cells with the angiotensin receptor antagonists plus vehicle served as control.

The antimitogenic actions of ANG II on bFGF-stimulated CEC were not influenced by losartan. In contrast, pretreatment of the cells with PD 123177 totally prevented the ANG IIinduced antiproliferation (Fig. 2, $b$ and $c$ and Table I). Neither of the two angiotensin receptor antagonists had an intrinsic effect on proliferating CEC (data not shown).

The AT2 agonist, CGP 42112, was found to mimic the antiproliferative effect of ANG I, but only at significantly higher concentrations $\left(10^{-6} \mathrm{M}\right)$. At lower concentrations, this compound competed for this effect of ANG II (Fig. 3).

Angiotensin receptor subtypes expressed by CEC and VSMC. VSMC in culture have been shown previously to express only AT1 receptors $(10,21,25)$. The subtypes of ANG II receptors expressed by CEC in culture at early passages $(\leq 3)$ were identified by radioligand binding experiments using the nonselective ANG II antagonist, $\left[{ }^{125}\right] \mathrm{Sar}^{1} \mathrm{Ile}^{8}$ ANG II, as a 
Table I. Effect of ANG II on Proliferation of Quiescent and bFGF-stimulated Rat Coronary Endothelial Cells (CEC) with or without Pretreatment with Losartan and PD 123177

\begin{tabular}{llc}
\hline & Cell number (quiescent CEC) & Cell number (bFGF-stimulated CEC) \\
\hline Control (vehicle-treated CEC) & $1.89 \times 10^{5} \pm 0.11 \times 10^{5}$ & $2.31 \times 10^{5} \pm 0.14 \times 10^{5}$ \\
ANG II $\left(10^{-7} \mathrm{M}\right)$ & $1.80 \times 10^{5} \pm 0.09 \times 10^{5}$ & $1.60 \times 10^{5} \pm 0.12 \times 10^{5 \ddagger}$ \\
Losartan $\left(10^{-5} \mathrm{M}\right)+$ ANG II $\left(10^{-7} \mathrm{M}\right)$ & $1.43 \times 10^{5} \pm 0.12 \times 10^{5}$ & $1.65 \times 10^{5} \pm 0.15 \times 10^{5 *}$ \\
PD $123177\left(10^{-6} \mathrm{M}\right)+$ ANG II $\left(10^{-7} \mathrm{M}\right)$ & $2.23 \times 10^{5} \pm 0.18 \times 10^{5 *}$ & $2.28 \times 10^{5} \pm 0.10 \times 10^{5}$ \\
\hline
\end{tabular}

Cell number was determined using a Coulter particle counter. Data shown are means of six experiments \pm SEM. ${ }^{*} P<0.05$ and ${ }^{\ddagger} P<0.01$ compared to vehicle-treated CEC. The table shows data from two different sets of experiments. In the second set of experiments (bFGF-treated cells) the mean value for quiescent CEC was $1.62 \times 10^{5} \pm 0.10 \times 10^{5}$ cells and the difference to bFGF-treated cells was significant with $P<0.05$.

tracer and the selective AT1 antagonist, losartan, and AT2 agonist, CGP 42112, as competing drugs. The experiments performed on membrane particulate yielded a $B_{\max }$ of 79.2 \pm 8.7 $\mathrm{fmol} / \mathrm{mg}$ protein and a $K_{\mathrm{i}}$ for ANG II of $0.3 \pm 0.07 \mathrm{nM}(n=$ 3 ). The competition binding experiments performed with losartan and CGP 42112 yielded complex curves suggesting the presence of two classes of binding sites (Fig. 4). Computerassisted analysis of the data (after subtraction of nonspecific binding) using a non linear curve fitting programm (17) confirmed the presence of two classes of binding sites with $K_{\mathrm{i}}$ values of respectively $40 \mathrm{nM}$ and $8.5 \mu \mathrm{M}$ for losartan and 0.24 $\mathrm{nM}$ and $1.7 \mu \mathrm{M}$ for CGP 42112. These values are in agreement with the previously reported affinities of these compounds for AT1 and AT2 receptors in other tissues and cultured cells (10, $16,26,28,34,35,36)$, thus indicating the expression of both receptor subtypes in culture. The ratio of AT1/AT2 receptors was calculated to be $\sim 80 \% / 20 \% \pm 5 \%$.

Analysis of AT1- and AT2-receptor mRNA expression in $C E C$. Specific mRNA transcripts for both ANG II receptor subtypes, AT1 and AT2, could be detected in CEC up to the third cell passage by PCR analysis. All PCR products were found to be of the predicted size on agarose gels. The specificity of the PCR reaction was tested by restriction enzyme analysis of amplified products which resulted in fragments of correct size (data not shown) as well as by hybridization of the PCR products to full length cDNA probes of AT1 and AT2 (Fig. 5).

\section{Discussion}

In preliminary studies we have reported that ANG II can inhibit the proliferation of coronary endothelial cells in vitro $(8,9)$. The present study confirms and extends our previous findings by demonstrating that distinct growth modulating actions of ANG II are coupled to different angiotensin receptor subtypes.

Several investigators have shown that ANG II is a growth promoting factor for VSMC $(1-5,20,21)$ and that this effect is mediated by the AT1-receptor (22). The results of the present study using VSMC isolated from the rat aorta confirm the findings of Geisterfer et al. (3) and Berk et al. (22). ANG II treatment engendered hypertrophy but not hyperplasia in aortic VSMC, since ANG II induced the synthesis of DNA (as reflected by the uptake of $\left[{ }^{3} \mathrm{H}\right]$ thymidine) but did not lead to an increased cell number. Thus far, an ANG II-induced hyperplasia has only been reported for aortic VSMC originating from SHR or for VSMC isolated from mesenteric arteries $(4,5,24)$.

The growth responses of VSMC to ANG II vary depending on the target VSMC, and the mechanisms leading to differential growth responses are still controversial. Dzau et al. (25) proposed that ANG II represents a bifunctional growth factor for VSMC by simultaneously stimulating proliferative and antiproliferative pathways that appear to be mediated by the activation of platelet-derived growth factor (PDGF)-AA and transforming growth factor (TGF- $\beta_{1}$ ) They reported that the mitogenic effect of ANG II was offset by the concomitant activation of TGF- $\beta_{1}$ which prevented proliferation. On the other hand, Stouffer and Owens (24) claimed that the ANG II-induced mitogenesis in VSMC derived from SHR was dependent on an autocrine production of TGF- $\beta_{1}$, potentiating the mitogenic properties of ANG II in the presence of epidermal growth factor (EGF) or PDGF-BB. The discrepancies between these studies concerning the responses of VSMC to ANG II could be due to the experimental conditions, e.g., the presence or absence of distinct growth factors such as EGF, PDGF, bFGF, or serum.

VSMC in culture express only AT1- but no AT2-receptors $(10,16,20,26)$. Thus, the trophic effects of ANG II causing hyperplasia or hypertrophy can only be ascribed to the AT1receptor. Accordingly, in our study, the AT1-receptor antagonist, losartan, blocked the hypertrophic actions of ANG II in VSMC while the AT2-receptor antagonist, PD 123177, was ineffective. In contrast to VSMC, ANG II given alone exerted no growth promoting actions in quiescent endothelial cells. Interestingly, treatment of quiescent CEC with losartan in combination with ANG II reduced ${ }^{3} \mathrm{H}$-thymidine uptake below basal levels of vehicle-treated, serum-deprived cells while losartan by itself had no effect. Since vehicle-treated cells revealed a $\left[{ }^{3} \mathrm{H}\right]$ thymidine uptake of about 10.000 counts per minute, it is conceivable that complete quiescence of the cells was not achieved by partial serum deprivation with DME + 1\% FCS. Therefore, this effect could be explained by the stimulation of AT2-receptors which were unmasked by blockade of the AT1receptors.

When quiescent CEC were pretreated with the AT2-receptor antagonist, PD 123177, a mitogenic action of ANG II could also be demonstrated in endothelial cells. Pretreatment with losartan in addition to PD 123177 abolished this effect. The endothelial cells used in this study express the AT1- as well as the AT2-receptor. Thus, the AT2-receptor blockade obviously unmasked the growth-promoting effect of the AT1-receptor in quiescent endothelial cells. Together, these findings in quiescent VSMC and CEC suggest that ANG II can only exert a mitogenic action through the AT1-receptor when the AT2-receptor is either absent (as in cultured VSMC) or inactivated (as observed after pretreatment with PD 123177 in CEC). 

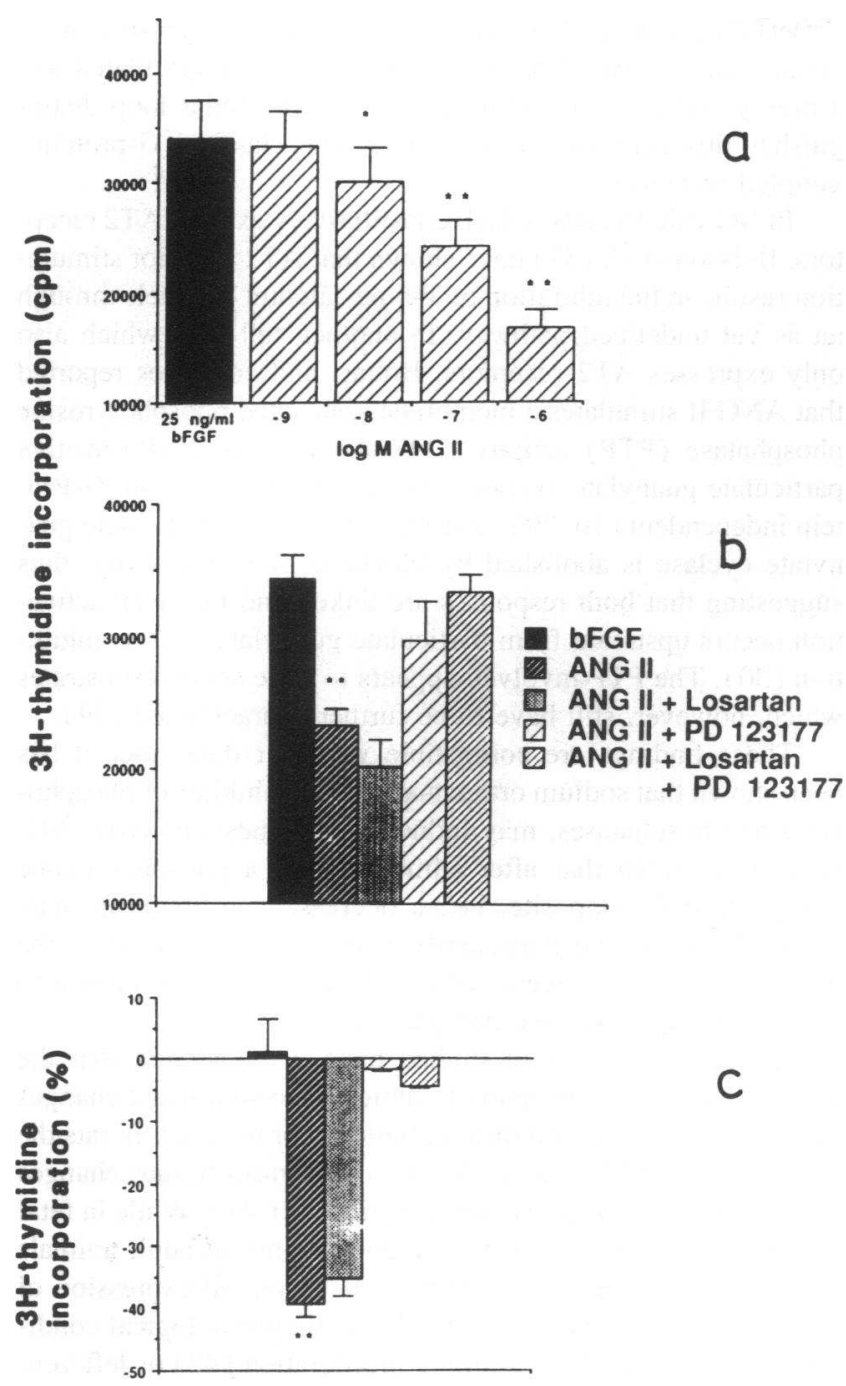

C

Figure 2. Antimitogenic effect of ANG II on CEC stimulated to proliferate by the addition of $25 \mathrm{ng} / \mathrm{ml}$ bFGF and effects of the ANG II receptor antagonists on the ANG II-induced inhibition of ${ }^{3} \mathrm{H}$-thymidine uptake in CEC $(n=8)$. (a) A dose-dependent decrease in $\left[{ }^{3} \mathrm{H}\right]$ thymidine uptake was observed at concentrations from $10^{-9}$ to $10^{-6} \mathrm{M}$. (b) the AT1-antagonist, losartan $\left(10^{-5} \mathrm{M}\right)$, was ineffective, while the AT2antagonist PD $123177\left(10^{-6} \mathrm{M}\right)$ completely prevented the antimitogenic effect of ANG II $\left(10^{-7} \mathrm{M}\right)$. (c) Data from $b$ as percentage of inhibition in comparison to vehicle-treated cells. ${ }^{*} P<0.05,{ }^{*} P<0.01$ in comparison with vehicle-treated cells in $a$ and to ANG II-treated cells in $b$ and $c$.

ANG II significantly inhibited growth of bFGF-stimulated proliferating endothelial cells in both assay systems used. Pretreatment of CEC with the AT2-antagonist, PD 123177, but not with the AT1-antagonist, losartan, prevented the ANG IIinduced endothelial antiproliferation indicating that this effect is mediated by the AT2-receptor subtype.

These findings are corrobated by the observations concerning the effect of the AT2 selective analog, CGP 42112. Whereas the antagonistic properties observed at low concentrations may appear to be in contradiction with its agonistic properties at higher concentrations, these data are in agreement with its partial agonistic properties reported recently in other systems (27-

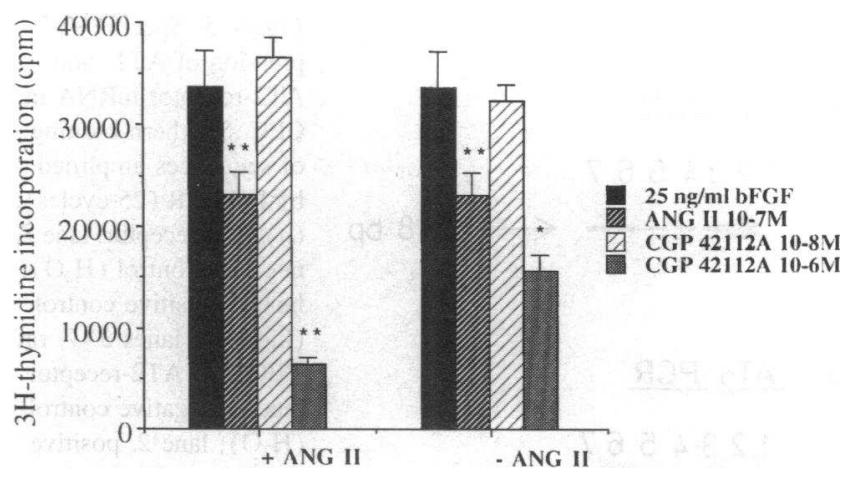

Figure 3. Antagonistic and agonistic properties of the AT2 receptor ligand, CGP 42112, on endothelial proliferation. At $10^{-8}$ M, CGP 42112 was antagonistic to ANG II $\left(10^{-7} \mathrm{M}\right)$ without having an intrinsic (antimitogenic) effect when given alone. At $10^{-6} \mathrm{M}$, CGP 42112 potentiated the antimitogenic effect of ANG II and was agonistic when given alone. $* P<0.05, * * P<0.001$ in comparison to vehicle-treated controls. $+A N G$ II, effect of CGP 42112 in the presence of ANG II $10^{-7} \mathrm{M}$; $-A N G$ II, effect of CGP 42112 alone.

30). Since this compound has the same affinity as ANG II for the AT2 receptor, but a lower intrinsic activity, it will compete with ANG II and inhibit its effect to a certain extent. At higher concentrations, the intrinsic activity appears to be sufficient to achieve the same final response as ANG II.

The question remains, as to how AT2-receptor stimulation can exert an antimitogenic action on proliferating endothelial cells in the presence of the AT1-receptor. It is conceivable that the growth-promoting AT1 effect of ANG II is inoperative in cells stimulated to proliferation by a potent growth factor such as bFGF. On the other hand, it is also possible that the AT2mediated antimitogenic effect dominates by a yet unknown mechanism over the growth-promoting actions of the AT1-receptor.

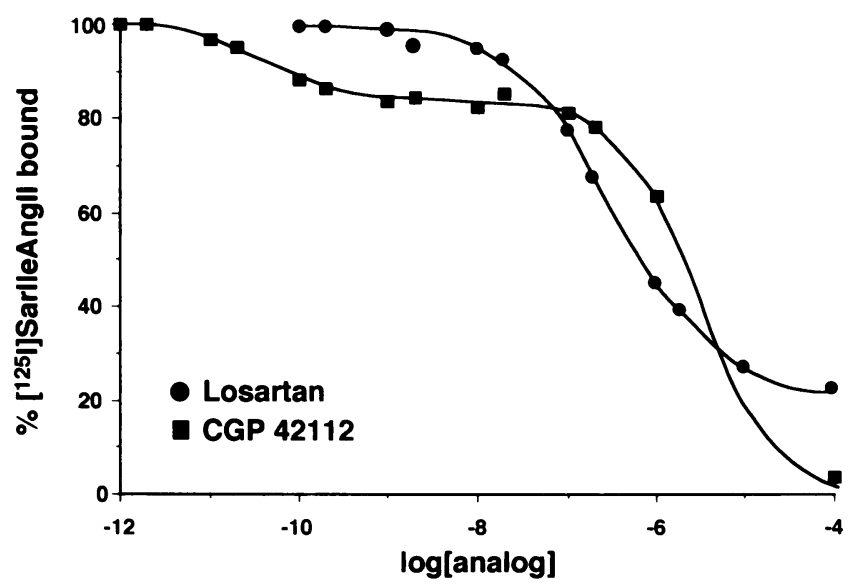

Figure 4. Competition of selective AT1- and AT2 receptor ligands for $\left.{ }^{125} \mathrm{I}\right] \mathrm{Sar}^{1} \mathrm{Ile}^{8} \mathrm{ANG}$ II binding to membrane particulate prepared from rat CEC. Plasma membrane particulate from CEC was incubated with $0.25 \mathrm{nM}\left[{ }^{125} \mathrm{I}\right] \mathrm{Sar}^{1} \mathrm{Ile}^{8} \mathrm{ANG}$ II and increasing concentrations of losartan $(\bullet)$ or CGP $42112(\square)$ for $90 \mathrm{~min}$ at $25^{\circ} \mathrm{C}$, as described in "Materials and Methods". Bound refers to specific binding determined as described above. Results shown are from a typical experiment. 


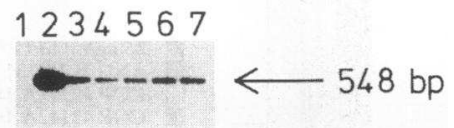

b

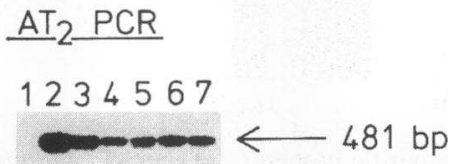

Figure 5. Specific expression of AT1- and AT2-receptor-mRNA in CEC. Southern blotting of sequences amplified by RT-PCR ( 25 cycles). (a) AT1-receptor: lane 1, negative control $\left(\mathrm{H}_{2} \mathrm{O}\right)$ lane 2 , positive control (kidney); lanes 3-7, rat CEC. (b) AT2-receptor: lane 1 , negative control $\left(\mathrm{H}_{2} \mathrm{O}\right)$; lane 2, positive control (pancreas), lanes 3-7, rat CEC

Our present findings are in apparent contrast to previous observations that ANG II has angiogenic properties in vivo (31, 32). Fernandez et al. (31) reported that ANG II, when implanted in the rabbit cornea, induced formation of new vessels. However, since the distribution of angiotensin receptors in the rabbit cornea may differ from that in CEC, the angiogenic effect of ANG II may be explained by stimulation of AT1-receptors in the absence of the AT2-receptor. Recently, Le Noble et al. (32) reported that ANG II induced angiogenesis in the chick chorioallantoic membrane. They postulated an involvement of a novel ANG II receptor subtype or the AT2-receptor in this effect. In their study, the AT2-ligand, CGP 42112, at a concentration of $2 \times 10^{-6} \mathrm{M}$ blocked the ANG II-induced angiogenesis while losartan as well as the nonpeptidergic AT2-antagonist, PD 123319, failed to significantly inhibit the angiogenic effect of ANG II. The observed effect of ANG II and its inhibition by CGP 42112 could be specific for the chick chorioallantoic membrane, since avian (33) and amphibian (34) ANG II receptors have been shown to differ from those in mammalian tissues. On the other hand, since a concentration of $2 \times 10^{-6} \mathrm{M}$ of CGP 42112A is agonistic for the AT2-receptor (see references cited above and this study) as well as antagonistic for the AT1receptor (28), the inhibition of ANG II-induced angiogenesis in the chick chorioallantoic membrane by this compound is difficult to interpret.

Little is known as of this writing on the function of the AT2-receptor. Although the AT2-receptor has recently been cloned $(35,36)$ its structure and signal transduction pathway are still far from being completely understood. The rat AT2receptor cDNA encodes for a 363-amino acid protein that has a seven transmembrane domain topology and a homology of $32-34 \%$ in its amino acid sequence to the AT1-receptor. However, it is still controversial whether it is coupled to G-proteins, and how it signals. Kambayashi et al. (35) reported that the rat AT2-receptor (expression cloned from a rat pheochromocytoma cell line) mediates an inhibition of a phosphotyrosine phosphatase in COS-7-cells (stably expressing the rat AT2-receptor). This effect is dependent on a pertussis toxin-sensitive, G-protein coupled mechanism. On the other hand, Mukoyama et al. (36) reported that the rat AT2-receptor shares a seven transmembrane domain topology which may belong to a unique class of seven transmembrane receptors for which G-protein coupling has not been demonstrated. In their studies, stimulation of the cloned AT2-receptor (transiently expressed in COS-7-cells) failed to increase $\mathrm{IP}_{3}$ or intracellular calcium, and no apparent

effects on cAMP and cGMP levels and phosphotyrosine phosphatase activity could be observed. The authors speculated that a highly conserved motif in the third intracellular loop distinguishes this class of receptors from the classical G-proteincoupled receptors.

In NG 108-15 cells, which constitutively express AT2 receptors, Buisson et al. (37) have shown that AT2 receptor stimulation results in the inhibition of T-type calcium channels through an as yet undefined pathway. In another cell line, which also only expresses AT2 receptors, Bottari and collegues reported that ANG II stimulates a membrane associated phosphotyrosine phosphatase (PTP) activity (29) and inhibits ANP-sensitive particulate guanylate cyclase $(30,38)$. Both effects are G-Protein independent $(16,29)$, and the inhibition of particulate guanylate cyclase is abolished by blockade of PTP activity, thus suggesting that both responses are linked and that PTP activation occurs upstream from particulate guanylate cyclase inhibition (30). The PTP involved appears to have several substrates which, however, still have to be further characterized (29).

These findings are compatible with our data since it has been shown that sodium orthovanadate, an inhibitor of phosphotyrosine phosphatases, may induce angiogenesis in vivo (39). It is conceivable that after stimulation of a phosphotyrosine phosphatase the opposite, i.e., a decreased proliferation, may occur. This may be particularly pertinent with regard to the inhibition of the mitogenic effect of bFGF which is known to involve multiple tyrosine phosphorilations.

Results from binding studies have demonstrated that the appearance of AT2-receptors is subjected to significant changes during development and differentiation. For instance, in rats the proportion of AT1- and AT2-receptors in most tissues changes dramatically during the postnatal period $(40,41)$. While in fetal tissues AT2-receptors are by far dominating, in adult animals it is the AT1-receptor. In addition, an increased expression of AT2-receptors has been described in pathophysiological conditions such as vascular neointima proliferation (42) or left ventricular hypertrophy due to aortic banding (43).

The observation of transient expression of the AT2-receptor during development together with that of an AT2-induced stimulation of phosphotyrosine phosphatase activity suggest that this receptor subtype is involved in the control of cell proliferation and differentiation. In view of the above mentioned and our present findings, one could speculate that a major function of the AT2-receptor is to tune down excessive proliferative actions of growth factors including those of ANG II via the AT1-receptor. This growth modulatory action of the AT2-receptor may be of particular importance during development or in pathophysiological situations involving remodelling and tissue repair.

\section{Acknowledgments}

The gift of the rat AT1 and AT2 cDNAs by Dr. T. Inagami (Vanderbilt University, Nashville, TN) to Dr. M. Paul is gratefully acknowledged.

\section{References}

1. Naftilan, A. J., R. E. Pratt, C. S. Eldridge, and V. J. Dzau. 1989. Angiotensin II induces c-fos expression in smooth muscle cells via transcriptional control. Hypertension. 13:706-711.

2. Katz, A. M. 1990. Angiotensin II; Hemodynamic regulator or growth factor? J. Mol. Cardiol. 22:739-747. 
3. Geisterfer A. A. T., M. J. Peach, and G. K. Owens. 1990. Angiotensin II induces hypertrophy but not hyperplasia of cultured rat aortic smooth muscle cells. Circ. Res. 62:749-756.

4. Paquet, J. L., M. Bandomin-Legros, G. Brunelle, and P. Meyer. 1990. Angiotensin II-induced proliferation of aortic myocytes in spontaneously hypertensive rats. J. Hypertens. 8:565-572.

5. Lyall, F. M., J. J. Morton, F. Lever, and E. J. Cragoe. 1988. Angiotensin II activates $\mathrm{Na}^{+}-\mathrm{H}^{+}$exchange and stimulates growth in cultured smooth muscle cells. J. Hypertens. 6 (suppl 4):S438-S441.

6. Aceto J. F., and K. M. Baker. 1990. (Sar1) angiotensin II receptor-mediated stimulation of protein synthesis in chick heart cells. Am. J. Physiol. 258:H806H813.

7. Unger, Th., T. Mattfeld, V. Lamberty, P. Bock, G. Mall, W. Linz, B. A. Schölkens, and P. Gohlke. 1992. Effect of early-onset angiotensin converting enzyme inhibition on myocardial capillaries. Hypertension. 20:476-482.

8. Metsärinne, K. P., M. Stoll, P. Gohlke, M. Paul, and Th. Unger. 1992. Angiotensin II is antiproliferative for coronary endothelial cells in vitro. Pharmaceut. Pharmacol. Lett. 2:150-152.

9. Stoll, M., K. P. Metsärinne, P. Gohlke, M. Paul, and Th. Unger. 1992. Proliferation of rat heart capillary endothelial cells is attenuated by angiotensin II. Hypertension. 20(Vol. 3):418( Abstr.)

10. de Gasparo, M., S. Whitebread, M. Mele, A. S. Montani, P. J. Whitecombe, H. P. Ramjoue, and B. Kamber. 1990. Biochemical characterization of two angiotensin II receptor subtypes in the rat. J. Cardiovasc. Pharmacol. 16(suppl. 4):S31-SS35.

11. Piper, H. M., R. Spahr, S. Mertens, A. Krützfeld, and H. Watanabe. 1990 Cell culture techniques in heart and vessel research. In Microvascular endothelial cells from the heart. H. M. Piper, editor. Springer Verlag Heidelberg, Berlin, New York. 159-177.

12. Voyta, J. C., D. P. Netland, D. P: Via, and B. R. Zetter. 1984. Specific labeling of endothelial cells using fluorescent acetylated-low density lipoprotein. J. Cell. Biol. 99:81 a (Abstr.)

13. Glaser, B. M., P. A. D'Amore, P. G. Michels, A. Patz, and A. Fenselau. 1980. Demonstration of vasoproliferative activity from mammalian retina. J. Cell Biol. 84:298-304.

14. Tada, H., O. Shiho, K. Kuroshima, M. Koyama, and K. Tsukamoto. 1986. An improved colorimetric assay for interleukin 2. J. Immunol. Methods. 93:157165.

15. Baird, A., and T. Durkin. 1986. Inhibition of endothelial cell proliferation by type $\beta$-transforming growth factor: Interactions with acidic and basic fibroblast growth factor. Biochem. Biophys. Res. Commun. 138:476-482.

16. Bottari, S. P., Taylor V., King I. N., Bogdal S, and M. de Gasparo. 1991. Angiotensin II AT2 receptors do not interact with guanine nucleotide binding proteins. Eur. J. Pharmacol. 207:157-163.

17. Mc Pherson, G. A. 1985. Analysis of radioligand binding experiments: a collection of computer programs for the IBM PC. J. Pharmacol. Methods. 14:213-228.

18. Chirgwin, J. A., A. Przbyla, R. McDonald, and W. J. Rutter. 1979. Isolation of biologically active ribonucleic acid from sources enriched in ribonuclease. Biochemistry. 18:5294-5299.

19. Paul, M., J. Wagner and V. J. Dzau. 1993. Gene expression of the ReninAngiotensin-System in human tissues. Quantitative analysis by the polymerase chain reaction. J. Clin. Invest. 91:2058-2064.

20. Campbell-Boswell, M. and A. L. Robertson. 1981. Effects of angiotensin II and vasopressin on human smooth muscle cells in vitro. Exp. Mol. Pathol. 35:265-276.

21. Owens, G. K., P. S. Rabinovitch, and S. M. Schwartz. 1981. Smooth muscle cell hypertrophy versus hyperplasia in hypertension. Proc. Natl. Acad. Sci. USA. 78:7759-7763.

22. Lyall, F., E. S. Dornan, J. McQueen, F. Boswell, and M. Kelly. 1992. Angiotensin II increases proto-oncogene expression and phosphoinositide turnover in vascular smooth muscle cells via the angiotensin II AT1 receptor. J. Hypertens. 10:1463-1469.

23. Berk, B. C., V. Vekhstein, H. M. Gordon, and T. Tsuda. 1989. Angiotensin II-stimulated protein synthesis in cultured vascular smooth muscle cells. Hypertension. 13:305-314.

24. Stouffer, G. A., and G. K. Owens. 1992. Angiotensin II-induced mitogen- esis of spontaneously hypertensive rat-derived cultured smooth muscle cells is dependent on autocrine production of transforming growth factor- $\beta 1$. Circ. Res. 70:820-828.

25. Dzau, V. J., G. H. Gibbons, and R. E. Pratt. 1991. Molecular Mechanisms of vascular Renin-Angiotensin System in myointimal hyperplasia. Hypertension. 18( suppl. II):100-105.

26. Timmermanns, P. B. M. W. M., P. C. Wong, A. T. Chiu, and W. F Herblin. 1991. Nonpeptide angiotensin II receptor antagonists. Trends Pharmacol. Sci. 12:55-61.

27. Brechler, V., P. W. Jones, N. R. Levens, M. deGasparo, and S. P. Bottari. 1993. Agonistic and antagonistic properties of angiotensin analogs at the AT2 receptor in PC 12W cells. Regul. Pept. 44:207-213.

28. Criscione, L., H. Thomann, S. Whitebread, M. deGasparo, P. Bühlmayer, P. Herold, F. Ostermayer, and B. Kamber. 1990. Binding characteristics and vascular effects of various angiotensin II antagonists. J. Cardiovasc. Pharmacol. 16( suppl 4):S56-S59.

29. Brechler, V., S. Reichlin, M. de Gasparo, and S. P. Bottari. 1994. Angioten$\sin$ II stimulates protein tyrosine phosphatase activity through a G-protein independent mechanism. Receptors and Channels 2:89-97.

30. Brechler, V., N. R. Levens, M. de Gasparo, and S. P. Bottari. 1994. Angiotensin $\mathrm{AT}_{2}$ Receptor mediated inhibition of particulate guanylate cyclase: A link with protein tyrosine phosphatase stimulation? Receptors and Channels. 2:79-87.

31. Fernandez, L. A., J. Twickler, and A. Mead. 1985. Neovascularization produced by angiotensin II. J. Lab. Clin. Med. 105:141-145.

32. Le Noble, F. A. C., N. H. J. S. Schreurs, H. W. M. Van Straaten, D. W Slaaf, J. F. M. Smits, H. Rogg, and H. A. J. Struiker-Boudier. 1993. Evidence fo a novel angiotensin II receptor involved in angiogenesis in chick chorioallantoic membrane. Am. J. Physiol. 264:R460-R465.

33. Stallone, J. N., H. Nishimura, and M. C. Khosla. 1989. Angiotensin I vascular receptors in fowl aorta: binding specificity and modulation by divalent cations and guanine nucleotides. J. Pharmacol. Exp. Ther. 252:1076-1082.

34. Sandberg, K., J. Hong, M. A. Millan, and K. J. Catt. 1991. Amphibian myocardial angiotensin II receptors are distinct from mammalian AT1 and AT2 receptor subtypes. FEBS (Fed. Eur. Biochem. Soc.) Lett. 284:281-284.

35. Kambayashi, Y., S. Bardhan, K. Tahahashi, S. Tsuzuki, H. Inui, T. Hamakubo, and T. Inagami. 1993. Molecular cloning of a novel angiotensin II receptor isoform involved in phosphotyrosine phosphatase inhibition. J. Biol. Chem. 268;33:24543-24546.

36. Mukoyama, M., M. Nakajama, M. Horiuchi, H. Sasamura, R. E. Pratt, and V. Dzau. 1993. Expression cloning of type 2 angiotensin II receptor reveals a unique class of seven-transmembrane receptors. J. Biol. Chem. 268;33:2453924542.

37. Buisson, B., Bottari S. P., de Gasparo M., Gallo P. N., and M. D. Payet. 1992. The angiotensin AT2 receptor modulates T-type calcium current in nondifferentated NG 108-15 cells. FEBS (Fed. Eur. Biochem. Soc.) Lett. 309:161 164.

38. Bottari, S. P., I. N. King, Y. Bogdal, S. Reichlin, I. Dahlstroem, N. Lydon, and M. de Gasparo. 1992. The angiotensin II AT2 receptor stimulates phospho tyrosine phosphatase activity and mediates inhibition of particulate guanylate cyclase. Biochem. Biophys. Res. Commun. 183:206-211.

39. Montesano, R., M. S. Pepper, D. Belin, J. D. Vassali, and L. Orci. 1988 Induction of angiogenesis in vitro by vanadate, an inhibitor of phosphotyrosinephosphatases. J. Cell. Physiol. 134:460-466.

40. Tsutsumi K., and J. M. Saveedra. 1991. Characterization and developmen of angiotensin II receptor subtypes (AT1 and AT2) in rat brain. Am. J. Physiol. 216:R209-R216.

41. Tsutsumi K., M. Visvanathan, C. Strömberg, and J. M. Saveedra. 1991 Type-1 and type-2 angiotensin II receptors in fetal rat brain. Eur. J. Pharmacol. 198:89-92.

42. Pratt, R. E., D. Wang, L. Hein, and V. J. Dzau. 1992. The AT2 isoform of the angiotensin II receptor mediates myointimal hyperplasia following vascular injury. Hypertension. 20;3:P52. (Abstr.)

43. Tang S. S., B. Diamant, H. Rogg, H. Schunkert, B. H. Lorell, and J. R. Ingelfinger. 1992. Rat hearts contain angiotensin II receptors that are downregulated and differentially expressed during hypertrophy. Hypertension. 20(Vol 3):3:88 (Abstr.) 